\title{
QUALITATIVE INVESTIGATION \\ OF STANDARDISATION IN SERVICE ORGANIZATIONS - A LEAN SERVICE VIEWPOINT
}

\author{
WIESŁAW URBAN \\ Bialystok University of Technology, POLAND \\ e-mail: w.urban@pb.edu.pl
}

RECEIVED
ACCEPTED
JEL
CLASSIFICATION
KEYWORDS

ABSTRACT
10 July 2017

15 December 2017

L80

customer service, standardisation, Lean Service

The issue of standardisation has not yet been widely researched in the service industry. At the same time standards are the main management methodology to achieve quality and repeatability in service delivery processes. Moreover, standards according to Lean methodology are a means of gathering and spreading knowledge across the organization. The study aims to investigate standardisation in service organizations in the light of the Lean Management framework. The study employs the qualitative research approach. A sample of 30 service managers were asked open-ended questions referring to existing standards. The gathered stories were processed according to content analysis principles. The study concludes that the current approach to service standardisation is very far from Lean Management, which is a huge challenge for Lean Service dissemination.

\section{Introduction}

Lean Management is a management methodology which is becoming more and more popular in many industries all over the world. Many companies have experienced outstanding productivity growth in recent decades thanks to this methodology. It was developed in Japanese companies over a period of several decades, and after the presentation of outstanding results it started to be desired by other companies from many industries, at first 
manufacturing ones. Now, the manufacturing world is pretty experienced in Lean principles and tools, as well as the Lean transformation process.

Lean Management in the service industry has not yet been widely introduced in companies. Lean methodology is being implemented by some service companies, and a slightly wider implementation is noticed in healthcare services (Burgess, Radnor, 2013), but there are still plenty of fields of ignorance as well as challenges related to the practical implementation of the Lean approach to services. This is because service organization is noticeably different from the manufacturing one, and its delivery system has different characteristics compared to the manufacturing system (Grönroos, 2007; Vargo, Lusch, 2004).

Standardisation consists in using standards within an organization, and standardisation is a main concept in the whole, fairly extensive Lean methodology. This study aims to identify how standardisation works in service organizations, and to what extent current practices of service standardisation are consistent with the Lean Management framework. The study employs the qualitative approach, and the empirical investigation takes advantage of the Critical Incident Technique.

\section{Standardisation in services}

Standardisation has being exploited by service organizations for a long time. A standard in the service literature is understand as a routinized process with well-defined tasks and an orderly flow of customers. So standardisation helps to provide uniformity in service quality because the process is easier to control (Fitzsimmons, Fitzsimmons, 2008, p. 77). In the service industry, the blueprints methodology is perceived as a powerful management tool (Bitner, Ostrom, Morgan, 2008). It is probably the most widespread approach to service standardisation. Some authors highlight that most services defy standardisation because of their variability and unpredictability (Haksever, Render, Russell, Murdick, 1999). The reason mostly lies in the fact that services are co-produced - they emerge with the simultaneous participation of the customer. According to research (Jylhä, Junnila, 2014), service employees, during the co-creation process, do not always know what the customers really require, so standardisation understood as routinization becomes more challenging.

The Toyota Production System is perceived as an unmatched model of Lean Management. Hino (2006) mentions that in the centre of Toyota's gene transmission are documented procedures. He calls the standardisation Toyota's DNA. Work standards form a management cornerstone of Toyota's system. It is a fundamental part of step by step improvement. Ohno (1988) from Toyota admires Henry Ford, who wrote that standardisation means nothing unless it means standardising upward. Today, in the Lean Management approach a standard is perceived as a documented expression of the best method known at a given point in time, and after improvement it is changed into a new standard.

The literature mentions two types of standardisation techniques in Lean Service: the service standard process as a method of doing work in a constant cycle time, and the standard operations display as a visualised sequence of process steps (Sarkar, 2008). Others (Haeckel, Carbone, Berry, 2003, p. 22) argue that pretty widely used blue prints are not sufficient because service standards need narratives which capture the tone and texture of the desired performance. Hunter's (2011) research reveals that frontline service staff are willing to go above and beyond their job descriptions to ensure total customer satisfaction. A glimpse at the literature suggests that there is absolutely no clear view on standardisation in the service organization, and that the Lean approach might be particularly inspiring in this field. 


\section{Research methodology}

Standards in the service industry are very rarely studied empirically. The idea of the study is to observe standardisation from a fairly new angle, which is the Lean Management methodology, so the qualitative research strategy is necessary. An in-depth insight into the investigated issue is allowed by employing the Critical Incident Technique for gathering the field data. As scholars underline, the Critical Incident Technique can be employed to investigate many different aspects of a service over the duration of an encounter's enactment (Wong, Sohal, 2003). This technique is based on getting people to tell stories about things which have happened to them (Lockwood, 1994). The stories gathered from the respondents are transcribed and analysed according to content analysis principles.

The respondents were recruited from randomly chosen service companies operating in the B2C market. Managers from 30 service companies were interviewed with open-ended questions. The query presented to respondents has a complex nature, and it was as follows: 'What do you associate with the notion 'standards' in the services you are working on? Describe as comprehensively as you can a standard you know, and how this standard works in your organization'. After the description of a standard a respondent was asked to describe another one if (s)he could. The answers were recorded and transcribed afterwards.

All in all 61 standards were identified in the provided stories. This means that this number of organizational routines are reported, each of them reflecting a particular issue within a service organization. Sometimes a respondent provided a series of service standards which in fact was only one standard devoted to one particular issue in an organization. Conversely, a respondent sometimes reported a long description as one standard which in fact was interpreted as several separate standards. The number of identified standards appeared only in the indepth analysis of the reported stories.

\section{What is standardised in service oryanizations?}

The crucial issue while performing content analysis. It is repeatedly studying and categorising the stories on standards to identify exactly what organization sphere/problem is standardized. A number of organizational issues/ spheres were identified as being objects of standardisation. They are listed in Table 1 below, along with numbers and percentages. The standards identified as individuals are not presented in the table.

Table 1. The groups of standards identified in interviewees' stories

\begin{tabular}{lccc}
\hline \multicolumn{1}{c}{ Category } & Number & Percentage of objects & Percentage of standards \\
\hline Staff outfit & 18 & 60 & 30 \\
Conversation with the customer & 8 & 27 & 13 \\
Customer treatment & 7 & 23 & 11 \\
Staff appearance & 5 & 17 & 8 \\
Cleanliness & 3 & 10 & 5 \\
Selected process steps & 3 & 10 & 5 \\
Customer service process & 2 & 7 & 3 \\
Service sequence & 2 & 7 & 3 \\
Telephone call & 2 & 7 & 3 \\
Access to information & 2 & 7 & 3 \\
\hline
\end{tabular}

Source: own studies. 
The most frequently appearing object of service standardisation is 'staff outfit', which appeared in $60 \%$ of entities, and its frequency is noticeably greater than any other. The object of these standards is the variety of elements worn by service staff. The standards are set to enforce the wearing of the company's uniforms and other clothing. It is noticeable that the standard of the staff outfit always exists as 'came from the outside', considering the viewpoint of service staff. And it is absolutely clear that these standards are stable for long time. They might change along with company brand renewal, but their main purpose is to strengthen the company's image. Apart from the visual identification of a company, these standards to some extent make a contribution to customer experience during service provision. In some cases the standard of staff outfit goes along with the standard of 'staff appearance' (identified in 5 entities, 17\%). This refers to how the staff should look, for example hair length or tattoo visibility. These standards are very similar in terms of objectives and existence conditions for 'staff outfit' standards.

Another standards group is devoted to conversation with customers (8 objects, $27 \%$ ). These standards are set to ensure that during conversations service staff communicate appropriately and show necessary respect to customers. Another group is 'customer treatment' (7,23\%). These standards regulate some staff behaviour while being in contact with customers. They are mostly about symbols, gestures and courtesy towards customers. Apart from the above-mentioned standard groups a few more are identified: standards of 'cleanliness', standardized 'selected process steps', 'customer service process', 'service sequence', 'telephone call' and 'access to information.' It is important that these standards are very similar to those mentioned in the previous paragraph. In terms of the manners of implementation they are set to the service line as come from outside.

\section{Identified service standards versus Lean Management framework}

The idea of the performed empirical investigation is to determine to what extent the standardisation currently practiced in the service industry is consistent with the standardisation typical for the Lean Management approach. The above-mentioned service standard types were deeply analysed in the light of Lean Management methodology. The most common standard, the staff outfit, is not consistent with any Lean methodology components. It does not diminish its importance, but the staff outfit standard does not fit in any way anything that is important in the Lean Management approach. Moreover, as clearly mentioned in the literature section, the Lean approach to standardisation relies upon standards prepared to improve them as a provisional state striving for improvement. The staff outfit standard operates in a different logic. It purpose is to force identical-looking clothes worn by staff in all service spots. The standards of staff appearance present exactly the same function and logic as staff outfit.

Other quite numerous standard groups also have no common points with the Lean Management framework. Conversation with the customer actually sets routines referring to the conditions of the service process, not just the process stream, and it does not bother the productivity of the stream. According to Lean methodology, the most important things happen in the value stream. Lean is focused on eliminating waste from the value stream. The standards of customer treatment also play a supplementary role in the core service process where the value stream is flowing.

Exploring all the recognized standards, the first noticeable similarity to the Lean Management framework is identified in the standard of cleanliness, and similar to it - 'the order'. Both these standards have something in common with technique 5S, popular in Lean Management. 5S is a popular technique of keeping order and cleanliness at workstations by operators (Urban, Mazurek, 2011). The 5 S method is partly aimed at people operating 
more productively in workstations and partly at building operators' personal engagement. The next three standards groups deal with the value stream, which is inevitably the focus point of Lean Management. These groups are as follow: selected process steps, customer service process, and service sequence. It is clear that these standards cover in their scope the flow of a main service process which is very similar to the Lean value stream. These standards concern some different sequences of the value stream or only selected spheres. The summary of the correspondence of identified service standards with Lean methodology is presented in Table 2. As is summed up, only 11 standards, $18 \%$ of all the standards (not entities), are compliant with Lean Management. But this compliance is not exact or complete.

Tahle 2. Standards' compliance with Lean Management

\begin{tabular}{lccc}
\hline \multicolumn{1}{c}{ Standards } & Number & Percentage & Lean components \\
\hline Cleanliness & 3 & 5 & 5S technique \\
The order & 1 & 2 & \\
Selected process steps & 3 & 5 & Value stream \\
Customer service process & 2 & 3 & \\
Service sequence & 2 & 3 & \\
\hline Total & 11 & 18 & \\
\hline
\end{tabular}

Source: own studies.

The main idea of Lean with regard to standardisation is to standardize to change the standard. This means that a standard is treated as a temporary solution that should eventually be improved, again and again. Along with this understanding of standardisation goes its bottom-line character. Teams of operators set up standards to eliminate waste and to prevent quality flaws within the value stream. In the Lean approach standards do not come from outside, nor from the top managers, nor from the company's central office, and nor from outer organizations. The operators are responsible for achieving some goals, and they set up, improve and set new standards. All the above-mentioned service standards identified in companies play a noticeably different role. All of them, from the point of view of the line staff, come from outside - from a franchisor, a company's central office, external advisors or top managers. This also applies to the five groups of standards qualified as to some extent being in accordance with the Lean Management framework, presented in Table 2 above.

\section{Conclusions}

The research on standardisation is not wide yet, and some stakeholders perceive it as a subordinate tool for getting more work from operators, or even to 'squeeze' them. But this view on standardisation is not appropriate, as Toyota proved that standardisation is an excellent method of capturing the best practical knowledge and to accumulate it and develop it; a standard forms an edge to bounce off to find a better solution. The Lean Management approach is approaching the service industry, bringing many hopes for improving performance and productivity. This study, based on qualitative in-depth studies, tried to confront existing service standards with the Lean Management framework. According to the performed content analysis and a deep understanding of the 61 standards existing in 
service companies, there are only two feeble tangent points with the Lean approach. These standards, which to some extent are close to Lean, represent only $18 \%$ of all the recognized service standards.

Although some potentially common points were identified, the discovered logic of standardisation is totally different than that practiced in Lean Management. The identified service standardisation serves as a tool for forcing some desired behaviours in distributed service spots. From the point of view of knowledge, this is one direction knowledge flow, from some centres to the service line. These are not symptoms of producing practical operational knowledge in service spots and capturing them in standards. It should be underlined that imposed standards are not well perceived and not easily accepted by executors - employees. The final conclusion is pretty clear: the discovered approach to service standardisation is very far from the approach practiced by Lean methodology. It shows a huge challenge in terms of Lean Management implementation in the service industry.

The conclusion that has emerged from this study is coherent with views recently appearing in the literature. Gupta, Sharma and Sunder (2016) argue that the Lean road to services is still in a nascent stage and needs much research. Suárez-Barraza, Smith and Dahlgaard-Park (2012) and Gupta et al. (2016) also point out the urgent need for Lean Service definitions and clarification of principles. Dos Reis Leite and Ernani Vieira (2015) postulate the identification of best practices and standards for Lean tools (like $5 S$ and process standardisation) referred to a service organization. Standardisation needs to discover its diametrically different face to be adopted in Lean Service transformation in a service organization.

\section{References}

Bitner, M.J., Ostrom, A.L., Morgan, F.N. (2008). Service Blueprinting: A practical technique for service innovation. California Management Review, 3 (50).

Burgess, N., Radnor, Z. (2013). Evaluating Lean in healthcare. International Journal of Health Care Quality Assurance, 3 (26).

dos Reis Leite, H., Ernani Vieira, G. (2015). Lean philosophy and its applications in the service industry: a review of the current knowledge. Production, 3 (25).

Fitzsimmons, J.A., Fitzsimmons, M.J. (2008). Service Management. Operations, Strategy, Information Technology. New York: McGraw Hill.

Grönroos, C. (2007). Service Management and Marketing. Customer Management in Service Competition (3-rd ed.). New York: John Willey \& Sons.

Gupta, S., Sharma, M., Sunder, V.M. (2016). Lean services: a systematic review. International Journal of Productivity and Performance Management, 8 (65).

Haeckel, S.H., Carbone, L.P., Berry, L.L. (2003). How to Lead the Customer Experience. Marketing Management, 1 (12).

Haksever, C., Render, B., Russell, R.S., Murdick, R.G. (1999). Service Management and Operations (2-nd ed.). Prentice Hall.

Hino, S. (2006). Inside the Mind of Toyota. New York: Productivity Press.

Hunter, J.A. (2011). A study of consumer perception of smiling customer service within the airline industry. Journal of Transportation Security, 1 (4).

Jylhä, T., Junnila, S. (2014). The state of value creation in the real-estate sector - lessons from lean thinking. Property Management, 1 (32).

Lockwood, A. (1994). Using Service Incidents to Identify Quality Improvement Points. International Journal of Contemporary Hospitality Management, 1/2 (6).

Ohno, T. (1988). The Toyota Production System: Beyond Large Scale Production. New York: Productivity Press.

Sarkar, D. (2008). Lean for Service Organizations and Offices. Milwaukee: ASQ Quality Press. 
Suárez-Barraza, M.F., Smith, T., Dahlgaard-Park, S.M. (2012). Lean Service: A literature analysis and classification. Total Quality Management \& Business Excellence, 3-4 (23).

Urban, W., Mazurek, A. (2011). The human factor in 5 S implementation: perspectives from Poland. Emerald Emerging Markets Case Studies.

Vargo, S.L., Lusch, R.F. (2004). Evolving to a new dominant logic for marketing. Journal of Marketing, 1 (68).

Wong, A., Sohal, A. (2003). A critical incident approach to the examination of customer relationship manage-ment in a retail chain: an exploratory study. Qualitative Market Research: An International Journal, 4 (6).

Cite this article aS: Urban, W. (2018). Qualitative investigation of standardisation in service organizations - a Lean Service viewpoint. European Journal of Service Management, 2 (26), 307-313. DOI: 10.18276/ejsm.2018.26-38. 